\title{
Soil water in small drainages farmed with no-tillage and inversion tillage in northeastern Oregon
}

\section{J.D. Williams and D.S. Robertson}

\begin{abstract}
Crop productivity in the semiarid inland Pacific Northwest, United States, is dependent on the capture and storage of precipitation as soil water. To maximize soil water in this region, the conventional crop strategy is a two-year cropping system in which winter wheat (Triticum aestivum L.) is grown after a 14 month fallow period. This system is popular in the intermediate precipitation zone (300 to $450 \mathrm{~mm}$ [12 to $18 \mathrm{in}$ ]) in northeastern Oregon because of its history of producing reliable yields under highly variable precipitation. Adopting no-tillage and increasing the types of crops and frequency with which they are grown has the potential to improve soil quality and crop productivity. Water is the primary limiting factor in this region. Evaluating how increased cropping intensity and no-tillage affect the soil water regime is key to understanding the performance of these practices. Crops were grown in two small, upland drainages using inversion tillage or no-tillage. The inversion tillage drainage was in a two-year winter wheat-fallow rotation $\left(\mathrm{W}_{\mathrm{f}}-\mathrm{F}\right)$, from 2001 through 2004. From 2005 through 2008, it was divided in two parts with $\mathrm{W}_{\mathrm{f}}-\mathrm{F}$ in one half and annual cropping in the second half for adaptive management where the following were grown: recropped wheat $\left(\mathrm{W}_{\mathrm{r}}\right)$, volunteer wheat $\left(\mathrm{W}_{\mathrm{v}}\right)$, and wheat recropped after volunteer wheat $\mathrm{W}_{\mathrm{w}}$ The no-tillage drainage was divided into four roughly equal areas and farmed in a four-year rotation, which was completed twice in eight years (2001 to 2008). The four phases of the rotation were chemical fallow-winter wheat-spring pea (Cicer arietinum L. or Pisum sativum L.)-winter wheat $\left(\mathrm{CF}-\mathrm{W}_{\mathrm{cf}}-\mathrm{SP}-\mathrm{W}_{\mathrm{sp}}\right)$. Mean crop yield was not significantly different between inversion tillage $\left(2.98 \pm 0.30 \mathrm{Mg} \mathrm{ha}^{-1}\left[1.33 \pm 0.14 \mathrm{tn} \mathrm{ac}^{-1}\right]\right)$ and no-tillage $(3.14 \pm 0.29 \mathrm{Mg}$ $\left.\mathrm{ha}^{-1}\left[1.40 \pm 0.13 \mathrm{tn} \mathrm{ac}^{-1}\right]\right)$. Crop yield in each rotation phase was significantly different $(p \leq$ 0.05) in the following ranked groups: $\mathrm{W}_{\mathrm{cf}} \sim \mathrm{W}_{\mathrm{f}} \sim \mathrm{W}_{\mathrm{w}}>\mathrm{W}_{\mathrm{sp}} \sim \mathrm{W}_{\mathrm{r}}>\mathrm{W}_{\mathrm{v}}>$ SP. Contrary to this expectation, precipitation use efficiency (PUE) was significantly greater in the inversion tillage $\left(0.019 \pm 0.002 \mathrm{Mg} \mathrm{ha}^{-1} \mathrm{~mm}^{-1}\left[7.0 \pm 0.6 \mathrm{bu} \mathrm{ac}^{-1}\right.\right.$ in $\left.\left.^{-1}\right]\right)$ than in the no-tillage $(0.015 \pm$ $\left.0.001 \mathrm{Mg} \mathrm{ha}^{-1} \mathrm{~mm}^{-1}\left[5.5 \pm 0.5 \mathrm{bu} \mathrm{ac}^{-1} \mathrm{in}^{-1}\right]\right)$ drainage. However, PUE among phases within each system differed significantly in the following ranked largest to smallest order: $\mathrm{W}_{\mathrm{f}} \sim \mathrm{W}_{\mathrm{cf}}$ $\mathrm{W}_{\mathrm{w}} \sim \mathrm{W}_{\mathrm{sp}} \sim \mathrm{W}_{\mathrm{r}} \sim \mathrm{W}_{\mathrm{v}}$, and SP. There was significantly more available water at the $30 \mathrm{~cm}(1$ $\mathrm{ft}$ ) depth in $\mathrm{W}_{\mathrm{cf}}$ before fall planting than in the $\mathrm{W}_{\mathrm{f}}$. Early attempts at adopting no-tillage in northeastern Oregon were unsuccessful, generally attributed to poor soil water conditions, particularly near the surface. Based on crop yields reported here, it appears that more recent no-tillage technology and management of crop residue has alleviated this concern. A wider variety of alternative spring crops is needed to more thoroughly evaluate and compare PUE in intensified cropping systems to the traditional two-year winter wheat/fallow system practiced in the intermediate precipitation zone in northeastern Oregon.
\end{abstract}

Key words: dryland systems_-no-tillage-Pacific Northwest-precipitation use efficiency

Water is the primary limiting factor for
crop production in the semiarid inland
Pacific Northwest (IPNW), United States.

This condition is of particular concern in the low precipitation zone $\left(<300 \mathrm{~mm} \mathrm{y}^{-1}[11.8\right.$ in $\mathrm{yr}^{-1}$ ]) (Machado et al. 2015; Schillinger and Papendick 2008), but also presents challenges in the intermediate precipitation

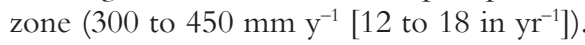
This precipitation zone occurs in a band between the lower Columbia Basin and a sharp increase in elevation of Palouse and foothills of the Blue Mountains. A defining characteristic of a semiarid environment is the variability around mean precipitation and temperatures in this region necessary for small grain production, particularly winter wheat (Triticum aestivum L.). If mean conditions are marginally suitable for small grain production, conditions are less than ideal half the time, and precipitation capture and storage as soil water are crucial for crop production (Schillinger and Young 2004).

Based on mean annual precipitation (MAP), annual or multicrop rotations with less frequent years of fallow (a.k.a. more intensive cropping) should be a viable option in the intermediate precipitation zone and have been adopted by many producers in the more northern reaches of the zone in Washington State. Producers in northeastern Oregon have been slower to adopt more intensive crop rotations (Machado et al. 2015; Smiley et al. 2005). There are a number of reasons for this slower rate of adoption, including lease agreements with absentee landowners, which can preclude changing from traditional farming practices, or decisions based on familial loyalty and history (Smiley et al. 2005; Williams et al. 2014). Ultimately, the enduring popularity of the two year winter wheat-fallow system in the IPNW is because it has historically produced consistent yields in highly variable seasonal and annual precipitation patterns.

Adopting no-tillage and increasing the mix of crops and frequency with which they are grown has the potential to improve soil quality and crop productivity (Gollany et al. 2011; Machado et al. 2015; Payne et al. 2000). No-tillage nearly eliminates soil erosion in this region, which has historically experienced some of the highest erosion rates recorded in winter wheat-fallow systems in the United States due to overland flow (50 $\mathrm{Mg} \mathrm{ha}^{-1} \mathrm{y}^{-1}$ [22.3 tn $\left.\mathrm{ac}^{-1} \mathrm{yr}^{-1}\right]$ ) (Williams et al. 2014; Zuzel et al. 1982). Some early adopters of no-tillage in the 1970s, however, experienced $50 \%$ decreases in winter wheat yields and subsequent loss of their farms (Smiley et al. 2005). Physical and biological explanations

John D. Williams is a research hydrologist and Dave S. Robertson is a registered geologist and hydrologic technician at the USDA Agricultural Research Service (ARS)-Columbia Plateau Conservation Research Center, Pendleton, Oregon. 
for these losses include poor germination resulting from a reduction in heat units due to excess residue, increased bulk density, and increased pressure from diseases and weeds (Felton et al. 1995; Hammel 1995; Johnson and Lowery 1985; Rasmussen and Parton 1994). Improved herbicides, equipment, and wheat varieties combined with 20 years of research and producers' innovations have improved no-tillage production in two-year wheat-fallow rotations (Williams and Long 2011; Williams and Wuest 2011; Williams et al. 2014). With little or no summer precipitation in this region, determining the soil water regimes under different management systems will aid in further development of farming methods that reduce the loss of precipitation captured the previous spring and winter. In the low precipitation zone of the IPNW, there is seldom sufficient autumn rainfall to wet the seed zone before planting before mid-October using no-tillage (Schillinger and Papendick 2008; Wuest and Corp 2011; Wuest and Schillinger 2011). In the intermediate precipitation zone, abundant surface residue and limited surface disturbance in no-tillage can maintain enough seed zone water for successful, and occasionally superior, annual and semiannual winter wheat production compared to mechanically prepared seed beds (Williams et al. 2000, 2015; Williams and Wuest 2014). However, there is reasonable doubt about how transferable knowledge gained from small plots can be to field scale, and memories of insufficient soil water for autumn planting from no-tillage efforts in the 1970 s remain.

No-tillage and increased crop frequency may improve the biological sustainability and the condition of the soil through enhanced soil organic matter (SOM) and improved soil structure (Duff et al. 1995; Huggins et al. 2011; Rasmussen et al. 1998). However the successful adoption of no-tillage practices in nonirrigated, rainfed crop production areas requires a better understanding of precipitation capture and soil water storage in order to lower the risk from water stress and improve stand establishment. In theory, a combination of less soil disturbance and maintenance of crop residue with increased cropping frequency should have positive effects or at a minimum maintain productivity compared to a two year rotation using inversion tillage. Our objective was to evaluate the productivity, soil water regime, and precipitation use efficiency in no-tillage with increased crop rotation compared to an inversion tillage based winter wheat-summer fallow system.

\section{Materials and Methods}

Site Description. Soil water content was measured in two upland ephemeral drainages in northeastern Oregon $\left(45^{\circ} 49^{\prime} 0.43^{\prime \prime}\right.$ $\left.\mathrm{N}, 118^{\circ} 38^{\prime} 35.46^{\prime \prime} \mathrm{W}\right)$. The soil within both drainages were Walla Walla silt loams (coarse-silty, mixed, super-active, mesic Typic Haploxerolls_-United States; KastanozemsFood and Agriculture Organization). Soil development occurred within a mantle of loess derived from Pleistocene aeolian deposits onto basalt flows of the Miocene epoch. These soils can be from tens of centimeters to tens of meters deep (Johnson and Makinson 1988). Low and high elevations in the drainages were $535.23 \mathrm{~m}(1,756.0 \mathrm{ft})$ and 557.23 $\mathrm{m}(1,828.2 \mathrm{ft})$ with slopes from $1 \%$ to $30 \%$. Meteorological records dating from 1931 at the USDA Columbia Plateau Conservation Research Center $11 \mathrm{~km}$ (6.8 mi) south of the research site show minimum and maximum air temperatures of $-34^{\circ} \mathrm{C}\left(-29^{\circ} \mathrm{F}\right)$ and $46^{\circ} \mathrm{C}\left(115^{\circ} \mathrm{F}\right)$, with a mean annual temperature of $11^{\circ} \mathrm{C}\left(52^{\circ} \mathrm{F}\right)$. Approximately $70 \%$ of precipitation occurs between November and April resulting from maritime polar air masses. Mean annual precipitation is 417 $\mathrm{mm}$ (16.41 in). Snow cover is transient, with accumulated snow subject to rapid melting by frequent warm fronts.

Crop Rotations. Initiated in 2000 and designed as a nonspatially replicated, sideby-side comparison of two cropping systems, we managed one 10.7 ha $(26.4 \mathrm{ac})$ drainage using no-tillage and the other 5.8 ha $(14.2$ ac) drainage using inversion tillage (Williams et al. 2009, 2014). The no-tillage drainage was divided into four approximately equal size plots cropped in a four-year rotation of chemical fallow-winter wheat-spring pea-winter wheat $\left(\mathrm{CF}-\mathrm{W}_{\mathrm{cf}}-\mathrm{SP}-\mathrm{W}_{\mathrm{sp}}\right.$; table 1) in which the pea was spring chickpea (Cicer arietinum L.) or dry spring pea (Pisum sativum L.). Each phase of the rotation was first randomly assigned to one of the plots (figure 1), after which the full rotation was completed twice from 2001 and 2008. The inversion tillage drainage was managed in a winter wheat-fallow rotation from 2001 through 2004. From 2005 through 2008, it was divided with the intention of managing it in an alternating sequence with one half in fallow and the other half in crop. However, after adaptive management decisions made by the cooperating farmer, the rotations and weed management were altered as shown in tables 1 and 2. In the no-tillage drainage, weeds in crop and fallow phases of the rotation were managed exclusively with herbicides. Herbicide applications were applied as needed in the fall pre- and postplanting, spring, and summer.

The inversion tillage drainage was managed using tillage equipment (moldboard or chisel plow, cultivator, rod-weeder) with minimal use of herbicides (table 2). Crop yield was determined from hand-harvested $1 \mathrm{~m}^{2}\left(11 \mathrm{ft}^{2}\right)$ plots in a stratified random assignment associated with transects of neutron probe access tubes running through the bottoms, toe, back, and top slopes of each drainage (figure 1).

Soil and Water Measurements. Beginning August 15, 2003, through July 18, 2008, soil volumetric water content measurements were made in each drainage capturing postharvest, midwinter, spring, and early summer conditions using a CPN 503DR neutron probe (CPN Corp., Pacheco, California) for neutron thermalization in $\sim 30 \mathrm{~cm}$ (1 $\mathrm{ft}$ ) increments. The neutron probe was field calibrated using soil samples collected during access tube installation to determine bulk densities across the site at all depths. Soil samples were oven dried at $105^{\circ} \mathrm{C}\left(221^{\circ} \mathrm{F}\right)$ and subsequent samples were collected from multiple locations, depths, and during wet and dry seasons. These efforts resulted in the following relationship:

$\theta=0.0032 \mathrm{C}-1.4499$

where $\mathrm{C}$ is the count. The standard error of the regression model estimation was $0.003 \mathrm{~m}^{3}$ $\mathrm{m}^{-3}$, with a correlation coefficient of 0.98 .

A total of 28 neutron probe access tubes were installed: 21 tubes to a depth of $1.8 \mathrm{~m}(6$

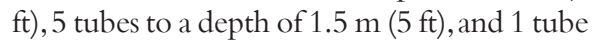
each to depths of 0.9 and $0.6 \mathrm{~m}$ (3 and $2 \mathrm{ft}$ ). The $1.5 \mathrm{~m}$ and two shallower depths were in soil overlaying a thick cemented caliche layer. Volumetric soil water (SW) was converted to depth values. Precipitation use efficiency (PUE) was calculated as the following:

$$
\begin{array}{r}
\text { PUE }\left(\mathrm{Mg} \mathrm{ha}^{-1} \mathrm{~mm}^{-1}\right)=\text { crop yield }\left(\mathrm{Mg} \mathrm{ha}^{-1}\right) \\
/[\Delta \mathrm{SW}(\mathrm{mm})+\mathrm{P}(\mathrm{mm})-\mathrm{RO}(\mathrm{mm})],(2)
\end{array}
$$

where crop yield is divided by change in soil water $(\Delta \mathrm{SW}$, measured before fall precipitation and again at or shortly after harvest) plus 
precipitation $(\mathrm{P})$ minus runoff $(\mathrm{RO})$ through the crop year. Measurements to determine precipitation recharge or PUE were made in later winter through early spring and late summer through early fall, and calculated with corresponding $\mathrm{P}$ and $\mathrm{RO}$ values. Soil profile recharge values were calculated by subtracting the crop year minimum measured in the autumn from the crop year maximum measured the following winter or spring. We assumed no drainage below the root zone based on three years of recently collected but unpublished data and research conducted by Chen and Payne (2001). Parshall flumes $(23 \mathrm{~cm}$ [9 in]) were installed at the mouth of each drainage. After large sediment loads in 2004 plugged the flume in the inversion tillage drainage it was replaced with a drop-box weir (Bonta 1998). Flow stage was recorded using ultrasonic distance sensors, and flow rate was calculated using the appropriate standard rating curve for flume or weir (Bonta 1998; USDI-BoR 2001). Runoff samples were collected using flow-activated, commercial storm water samplers using a liquid level switch at a stage of $1 \mathrm{~cm}$ (0.4 in) or greater. Storm water samples $(0.5 \mathrm{~L}$ [0.1 gal]) were collected every 40 minutes when overland flow occurred. Samples were analyzed for suspended sediment concentrations (Glysson and Gray 2002). Runoff and soil erosion results were reported in Williams et al. (2014).

Ground Cover. Crop residue was measured in $10,1 \mathrm{~m}^{2}\left(11 \mathrm{ft}^{2}\right)$ plots randomly located on transects within each drainage. Percentage ground cover was measured using a digital adaptation of the 100 point cross-hair frame method developed by Floyd and Anderson (1982).

Statistical Analysis. The paired drainage design (figure 1) establishes conditions of pseudoreplication through a lack of spatially random assignment of main treatments (no-tillage and inversion tillage) (Hurlbert 1984). Our purpose was to evaluate the conservation and hydrologic attributes of these rotations at the field scale making spatial, random replication problematic with the land available to conduct the research. However, the crop phases in each drainage were based on spatially and temporally random assignments the first year of each rotation. Data from the chickpea and dry spring pea crops were combined for analysis of soil water parameters. Statistical comparisons of soil water values and PUE were

\section{Table 1}

Annual precipitation and rainfed crop rotations in a drainage experiment used to evaluate runoff, soil erosion, and crop production under no-tillage and inversion tillage.

\begin{tabular}{|c|c|c|c|c|c|c|c|}
\hline \multirow{2}{*}{$\begin{array}{l}\text { Crop } \\
\text { year }\end{array}$} & \multirow{2}{*}{$\begin{array}{l}\text { Precipitation } \\
(\mathrm{mm})\end{array}$} & \multicolumn{4}{|c|}{ No-tillage } & \multicolumn{2}{|c|}{ Inversion tillage } \\
\hline & & Plot 1 & Plot 2 & Plot 3 & Plot 4 & Plot 5 & Plot 6 \\
\hline 2001 & 390 & $\mathrm{SP}_{\mathrm{c}}$ & $\mathrm{CF}$ & $\mathrm{W}_{\mathrm{s}}$ & $\mathrm{W}_{\mathrm{cf}}$ & $\mathrm{F}$ & $\mathrm{F}$ \\
\hline 2002 & 328 & $W_{s p}$ & $\mathrm{~W}_{\mathrm{cf}}$ & $\mathrm{CF}$ & $\mathrm{SP}_{\mathrm{c}}$ & $W_{f}$ & $W_{f}$ \\
\hline 2003 & 374 & $\mathrm{CF}$ & $\mathrm{SP}_{\mathrm{c}}$ & $\mathrm{W}_{\mathrm{cf}}$ & $\mathrm{W}_{\mathrm{sp}}$ & $\mathrm{F}$ & $\mathrm{F}$ \\
\hline 2004 & 508 & $W_{c f}$ & $\mathrm{~W}_{\mathrm{sp}}$ & $\mathrm{SP}_{\mathrm{c}}$ & $\mathrm{CF}$ & $W_{f}$ & $W_{f}$ \\
\hline 2005 & 309 & $\mathrm{SP}_{\mathrm{d}}$ & $\mathrm{CF}$ & W & $\mathrm{W}_{\mathrm{cf}}$ & $\mathrm{F}$ & $W_{r}$ \\
\hline 2006 & 495 & $\mathrm{~W}_{\mathrm{sp}}$ & $\mathrm{W}_{\mathrm{cf}}$ & $\mathrm{CF}$ & $\mathrm{SP}_{\mathrm{d}}$ & $W_{f}$ & $\mathrm{~W}_{\mathrm{v}}$ \\
\hline 2007 & 411 & $\mathrm{CF}$ & $\mathrm{SP}_{\mathrm{d}}$ & $\mathrm{W}_{\mathrm{cf}}$ & $\mathrm{W}_{\mathrm{sp}}$ & $\mathrm{F}$ & $\mathrm{W}_{\mathrm{w}}$ \\
\hline 2008 & 354 & $W_{c f}$ & $W_{s p}$ & $\mathrm{SP}_{d}$ & $\mathrm{CF}$ & $W_{f}$ & $\mathrm{~F}$ \\
\hline
\end{tabular}

Notes: $\mathrm{W}_{\text {of }}=$ winter wheat following chemical fallow. $\mathrm{SP}=$ spring chickpea. $\mathrm{SP}=$ dry spring peas $W_{s p}=$ winter wheat after spring pea. $W_{f}=$ winter wheat following tillage fallow. $W_{r}=$ recropped winter wheat. $\mathrm{W}=$ a one-time spring wheat crop necessary to establish the four year rotation. $\mathrm{W}_{\mathrm{v}}=$ volunteer winter wheat. $\mathrm{W}_{\mathrm{w}}=$ winter wheat after volunteer winter wheat. Chemical (CF) or inversion tillage $(F)$ fallow was 14 months.

\section{Figure 1}

Access tube locations for neutron gauge soil water measurements in no-tillage and inversion tillage upland drainages, northeastern Oregon.

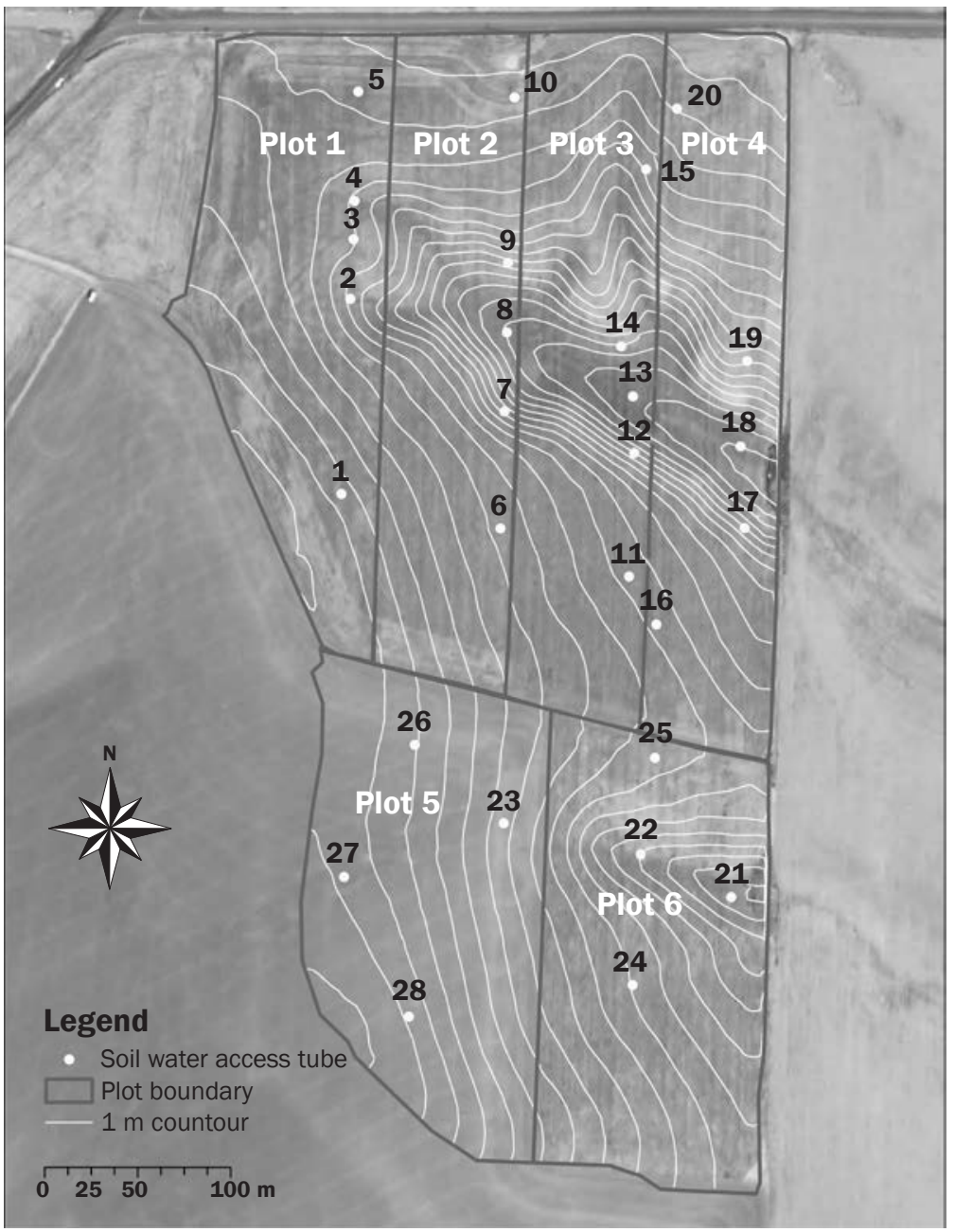


Table 2

Two years of representative weed management in a drainage experiment used to evaluate runoff, soil erosion, and crop production under no-tillage and inversion tillage dryland crop production.

\begin{tabular}{|c|c|c|c|c|c|c|c|c|}
\hline $\begin{array}{l}\text { Crop } \\
\text { year }\end{array}$ & Date & $\begin{array}{l}\text { Inversion } \\
\text { tillage } \\
\text { rotation }\end{array}$ & $\begin{array}{l}\text { Chemical or } \\
\text { mechanical operation* }\end{array}$ & $\begin{array}{l}\text { Rate } \\
\left(\text { L ha }^{-1}\right)\end{array}$ & Date & $\begin{array}{l}\text { No-tillage } \\
\text { rotation }\end{array}$ & $\begin{array}{l}\text { Chemical } \\
\text { operation }\end{array}$ & $\begin{array}{l}\text { Rate } \\
\left(\text { L ha }^{-1}\right)\end{array}$ \\
\hline \multirow[t]{13}{*}{2004} & Sept. 5, 2004 & $\mathrm{~F}$ & Burn, moldboard plow, fertilize & 0.02 & Feb. 19, 2004 & $\mathrm{CF}, \mathrm{SP}_{\mathrm{c}}$ & Roundup & 1.75 \\
\hline & Oct. 5, 2004 & $\mathrm{~F}$ & Cultivate & & Feb. 19, 2004 & $\mathrm{CF}, \mathrm{SP}_{\mathrm{c}}$ & Spartan & 0.37 \\
\hline & Apr. 15, 2004 & W & Ally & 0.02 & Mar. 3, 2004 & $\mathrm{SP}_{\mathrm{c}}$ & Pursuit & 0.11 \\
\hline & & & & & Mar. 3, 2004 & $\mathrm{SP}_{\mathrm{c}}$ & Trifluralin & 1.17 \\
\hline & & & & & Mar. 23, 2004 & W & Sencor & 0.37 \\
\hline & & & & & Mar. 24, 2004 & W & Banvel & 0.29 \\
\hline & & & & & Mar. 24, 2004 & W & Maverick & 0.05 \\
\hline & & & & & Apr. 2, 2004 & $\mathrm{SP}_{\mathrm{c}}$ & Sencor & 0.37 \\
\hline & & & & & Apr. 29, 2004 & $\mathrm{CF}$ & Roundup & 2.34 \\
\hline & & & & & Apr. 24, 2004 & $\mathrm{CF}$ & Banvel & 2.34 \\
\hline & & & & & July 1, 2004 & $\mathrm{SP}_{\mathrm{c}}$ & Amistar & 0.29 \\
\hline & & & & & July 15, 2004 & $\mathrm{CF}$ & Roundup & 1.90 \\
\hline & & & & & July 15, 2004 & $\mathrm{CF}$ & Banvel & 0.29 \\
\hline \multirow[t]{11}{*}{2005} & Sept. 5, 2004 & $\mathrm{~F}$ & Chisel plow, fertilize & & Feb. 8, 2004 & W & Maverick & 0.05 \\
\hline & Oct. 5, 2004 & $\mathrm{~F}$ & Cultiweed & & Feb. 8, 2004 & W & Sencor & 0.29 \\
\hline & Apr. 15, 2005 & $F, W_{r}$ & Cultivate, Ally & 0.02 & Mar. 3, 2005 & $\mathrm{CF}, \mathrm{SP}_{\mathrm{d}}$ & Roundup & 1.75 \\
\hline & May 15, 2005 & $\mathrm{~F}$ & Cultivate, fertilize & & Mar. 18, 2005 & $C F, \mathrm{SP}_{\mathrm{d}}$ & Spartan & 0.37 \\
\hline & June 15, 2005 & $\mathrm{~F}$ & Cultiweed & & Apr. 5, 2005 & $\mathrm{SP}_{\mathrm{d}}$ & Pursuit & 0.22 \\
\hline & July 10, 2005 & $\mathrm{~F}$ & Rodweed & & May 24, 2005 & $\mathrm{SP}_{\mathrm{d}}$ & Assure & 0.73 \\
\hline & Sept. 15, 2005 & $\mathrm{~F}$ & Rodweed & & June 4, 2005 & $\mathrm{CF}$ & Roundup & 1.90 \\
\hline & & & & & June 4, 2005 & CF & Banvel & 0.29 \\
\hline & & & & & July 13, 2005 & CF & Roundup & 1.90 \\
\hline & & & & & July 13, 2005 & $\mathrm{CF}$ & Banvel & 0.29 \\
\hline & & & & & July 25, 2005 & $\mathrm{SP}_{d}$ & Gramoxone & 1.56 \\
\hline
\end{tabular}

Notes: $\mathrm{SP}_{\mathrm{c}}=$ chickpea. $\mathrm{SP}_{\mathrm{d}}=$ dry spring peas. $\mathrm{W}$ = winter wheat. $\mathrm{W}_{\mathrm{r}}=$ recropped winter wheat. Chemical $(\mathrm{CF})$ or inversion tillage $(\mathrm{F})$ fallow was 14 months.

*Ally (metsulfuron methyl, DuPont, Wilmington, Delaware); Amistar (azoxystrobin, Syngenta, Greensboro, North Carolina); Assure (quizalofop p-ethyl DuPont, Wilmington, Delaware); Banvel (dicamba, BASF, Florham Park, New Jersey); Gramoxone (paraquat dichloride, Syngenta, Greensboro, North Carolina); Maverick (sulfosulfuron, Monsanto, St. Louis, Missouri); Pursuit (ammonium salt of imazethapyr, BASF, Florham Park, New Jersey); Roundup (glyphosate, Monsanto, St. Louis, Missouri); Sencor (metribuzin, Bayer, Research Triangle Park, North Carolina); Spartan (sulfentrazone, FMC, Philadelphia, Pennsylvania); Trifuralin (trifluralin 480 EC in xylene, Dow, Indianapolis, Indiana).

conducted first between the main treatments of inversion tillage and no-tillage, and then amongst individual phases in each rotation.

Because of adaptive management decisions made within the inversion tillage drainage, a number of crops (i.e., recropped winter wheat $\left[\mathrm{W}_{\mathrm{r}}\right]$, volunteer winter wheat $\left[\mathrm{W}_{\mathrm{v}}\right]$, and winter wheat recropped after the volunteer crop $\left[\mathrm{W}_{\mathrm{w}}\right]$ ) were grown for a single year, not replicated in time, creating an unbalanced experimental design. Samples from within these treatments were collected from multiple locations within the treatment area, from which a mean value was drawn to compare soil water, precipitation use efficiencies, and yields to the full, multiyear data sets from the other treatments, thus providing a weak estimation of the relative performances.

All data were analyzed using PROC GLIMMIX model in SAS 9.4 (Littell et al.
2006; SAS 2012). Differences were considered significant at $p \leq 0.05$. Sample sizes for each rotation phase and parameter are given in table 3 .

\section{Results and Discussion}

Our original objective was to compare the four-year and two-year rotations. With the adaptive management adopted in the inversion tillage drainage, this objective was compromised, and resulted in three crops with only one year of data $\left(\mathrm{W}_{\mathrm{r}}, \mathrm{W}_{\mathrm{v}}\right.$, and $\left.\mathrm{W}_{\mathrm{w}}\right)$. Although less than ideal from an experimental design point of view, these measurements provided an opportunity to look at the effects of annual cropping in the inversion tillage relative to the second and third crops in the four year, no-tillage rotation.

Tillage practices resulted in similar harvested biomass but significantly different crop residue ground cover. Mean total harvested biomass (all crop data pooled) was not significantly different between the inversion tillage $\left(2.98 \pm 0.30 \mathrm{Mg} \mathrm{ha}^{-1}[1.33 \pm 0.14 \mathrm{tn}\right.$ $\left.\left.\mathrm{ac}^{-1}\right]\right)$ and no-tillage $\left(3.14 \pm 0.29 \mathrm{Mg} \mathrm{ha}^{-1}\right.$ $\left.\left[1.40 \pm 0.13 \mathrm{tn} \mathrm{ac}^{-1}\right]\right)$ drainages indicating that tillage was not a significant factor controlling the yields. Over winter ground cover by crop residue was significantly greater in the no-tillage $(73 \% \pm 4 \%)$ than in the inversion tillage $(44 \% \pm 16 \%)$. Volunteer and recropped wheat had similar yields in which no significant differences were observed for the rotations for $\mathrm{W}_{\mathrm{w}}$, or $\mathrm{W}_{\mathrm{sp}}, \mathrm{W}_{\mathrm{r}}$, and $\mathrm{W}_{\mathrm{w}}$ (figure 2). The spring pea rotation produced significantly less yield than any other crop. Dry spring peas are typically grown in a high precipitation zone (450 to $580 \mathrm{~mm}$ [18 to 24 in]) and produce $2,240 \mathrm{~kg} \mathrm{ha}^{-1}\left(2,000 \mathrm{lb} \mathrm{ac}^{-1}\right)$ (Bragg et al. 2000), substantially more than 
we were able to achieve in this lower precipitation zone (chickpea 1,053 $\pm 236 \mathrm{~kg} \mathrm{ha}^{-1}$ $\left[1,179 \pm 264 \mathrm{lb} \mathrm{ac}^{-1}\right]$; dry green pea 1,590 $\pm 56 \mathrm{~kg} \mathrm{ha}^{-1}\left[1,781 \pm 63 \mathrm{lb} \mathrm{ac}{ }^{-1}\right]$; mean shown in figure $2, \mathrm{SP})$. Ground cover has been shown to play an important role in the capture and storage of soil water (Williams and Long 2011; Williams and Wuest 2011; Williams et al. 2014), and the difference between treatments here should have contributed to substantially better capture and storage of soil water.

As noted above, intensifying crop rotations may improve the biological sustainability and the condition of the soil through enhanced SOM and improved soil structure (Duff et al. 1995; Huggins et al. 2011; Rasmussen et al. 1998). Because water is the limiting factor in crop production in this region, positive changes might therefore be expected in PUE with cropping intensification. Contrary to this expectation, PUE was significantly greater in the inversion tillage $(0.02 \pm 0.00$ $\left.\mathrm{Mg} \mathrm{ha}^{-1} \mathrm{~mm}^{-1}\left[0.21 \pm 0.02 \mathrm{tn} \mathrm{ac}^{-1} \mathrm{in}^{-1}\right]\right)$ than in the no-tillage $\left(0.01 \pm 0.00 \mathrm{Mg} \mathrm{ha}^{-1} \mathrm{~mm}^{-1}\right.$ $\left.\left[0.16 \pm 0.01 \mathrm{tn} \mathrm{ac}^{-1} \mathrm{in}^{-1}\right]\right)$ drainage. This resulted from the significantly lower productivity of the SP, whereas the $\mathrm{W}_{\mathrm{cf}}$ performed as well as the $\mathrm{W}_{\mathrm{f}}$ (figure 2 ). The SP yield (1.32 $\left.\pm 0.15 \mathrm{Mg} \mathrm{ha}^{-1}\left[1,480 \pm 170 \mathrm{lb} \mathrm{ac}^{-1}\right]\right)$ was poor compared to yields $\left(\approx 2.20 \mathrm{Mg} \mathrm{ha}{ }^{-1}\right.$ $\left.\left[1,800 \mathrm{lb} \mathrm{ac}^{-1}\right]\right)$ grown with disk or plow seed bed preparation in a nearby location (Payne et al. 2000), suggesting that our no-tillage methods were not appropriate. Seeding and fertilizer rates were based on pre-seeding soil water and nitrogen $(\mathrm{N})$ test, thus all application rates were the same for $\mathrm{W}_{\mathrm{sp}}$ and $\mathrm{W}_{\mathrm{cf}}$ throughout the experiment. Weather-related growing conditions do not appear to be a factor; a review of long term weather records to crop years 2004 to 2008 indicates that conditions were only marginally outside the respective 95\% confidence intervals for spring time precipitation $(-1.0 \mathrm{~mm}[-0.04$ in]) and temperatures $\left(-0.4^{\circ} \mathrm{C}\left[-0.2^{\circ} \mathrm{F}\right]\right)$. The relatively dry conditions left by the $\mathrm{W}_{\mathrm{cf}}$ crop (figure 3) were alleviated through the winter before the seeding SP in April (figure 4). As the third crop in as many years, lower yields might be expected from the $\mathrm{W}_{\text {sp }}$ if soil water had been depleted by the previous two crops (figure 2). However, autumn soil water values at incremental depths (table 4) were not significantly different from those in $\mathrm{W}_{\mathrm{f}}$ or $\mathrm{W}_{\mathrm{cf}}$. Outside of these conditions, we cannot

\section{Table 3}

Sample size $(n)$ for analysis conducted on soil water and crop production parameters measured in two small upland drainages in the inland Pacific Northwest, United States.

\begin{tabular}{|c|c|c|c|c|c|c|c|c|c|}
\hline \multirow{2}{*}{$\begin{array}{l}\text { Analysis } \\
\text { (sample size [n])* }\end{array}$} & \multicolumn{4}{|c|}{ No-tillage } & \multicolumn{5}{|c|}{ Inversion tillage } \\
\hline & $\mathbf{w}_{\mathrm{cf}}$ & SP & $\mathbf{w}_{\mathrm{sp}}$ & CF & $w_{f}$ & $\mathbf{w}_{r}$ & $\mathbf{W}_{\mathrm{v}}$ & $\mathbf{w}_{w}$ & $\mathbf{F}$ \\
\hline Yield & 30 & 30 & 30 & NA & 12 & 4 & 4 & 4 & NA \\
\hline PUE & 30 & 30 & 30 & NA & 12 & 4 & 4 & 4 & NA \\
\hline SW & 120 & 120 & 120 & 120 & 67 & 16 & 20 & 16 & 53 \\
\hline $\mathrm{SW}_{\max }$ & 20 & 20 & 20 & 20 & 12 & 4 & 4 & 4 & 12 \\
\hline $\mathrm{SW}_{\min }$ & 20 & 20 & 20 & 20 & 12 & 4 & 4 & 4 & 12 \\
\hline
\end{tabular}

Notes: $\mathrm{W}_{\mathrm{of}}=$ winter wheat following chemical fallow. $\mathrm{SP}=$ spring chickpea. $\mathrm{SP}_{\mathrm{d}}=$ dry spring peas. $\mathrm{W}_{\mathrm{sp}}=$ winter wheat after spring pea. $\mathrm{W}_{\mathrm{f}}=$ winter wheat following tillage fallow. $\mathrm{W}_{\mathrm{r}}=$ recropped winter wheat. $\mathrm{W}_{\mathrm{s}}=\mathrm{a}$ one-time spring wheat crop necessary to establish the four year rotation. $\mathrm{W}_{v}=$ volunteer winter wheat. $\mathrm{W}_{w}=$ winter wheat after volunteer winter wheat. NA = not applicable, no crop grown. Chemical (CF) or inversion tillage (F) fallow was 14 months.

*Yield $=$ crop yield $\left(\mathrm{Mg} \mathrm{ha}^{-1}\right) . \mathrm{PUE}=$ precipitation use efficiency $\left(\mathrm{Mg} \mathrm{ha}^{-1} \mathrm{~mm}^{-1}\right) . \mathrm{SW}=$ soil water $\left(\mathrm{mm}\right.$ ) values from all measurement from 2003 through 2008, SW max $_{\text {and }} \mathrm{SW}_{\text {min }}$ soil water measurements in winter through spring when soil profile were recharged with water (max), and between harvest and autumn seeding when soil water levels were most depleted ( $\mathrm{min}$ )

\section{Figure 2}

Crop yields and precipitation use efficiency from no-tillage and inversion tillage in northeastern Oregon. Different column letters indicate significant differences between columns $(p \leq 0.05)$ within respective parameters of crop yield or precipitation use efficiency (PUE). $\mathrm{W}_{\mathrm{cf}}=$ winter wheat following chemical fallow. $\mathrm{SP}=$ spring peas following winter wheat. $\mathrm{W}_{\mathrm{sp}}=$ winter wheat following spring peas. $\mathrm{W}_{\mathrm{f}}=$ winter wheat following inversion tillage fallow. $\mathrm{W}_{\mathrm{r}}=$ recropped winter wheat following winter wheat. $W_{v}=$ volunteer winter wheat following recropped winter wheat. $\mathrm{W}_{\mathrm{w}}=$ winter wheat following volunteer winter wheat. Chemical or inversion tillage fallow was 14 months.

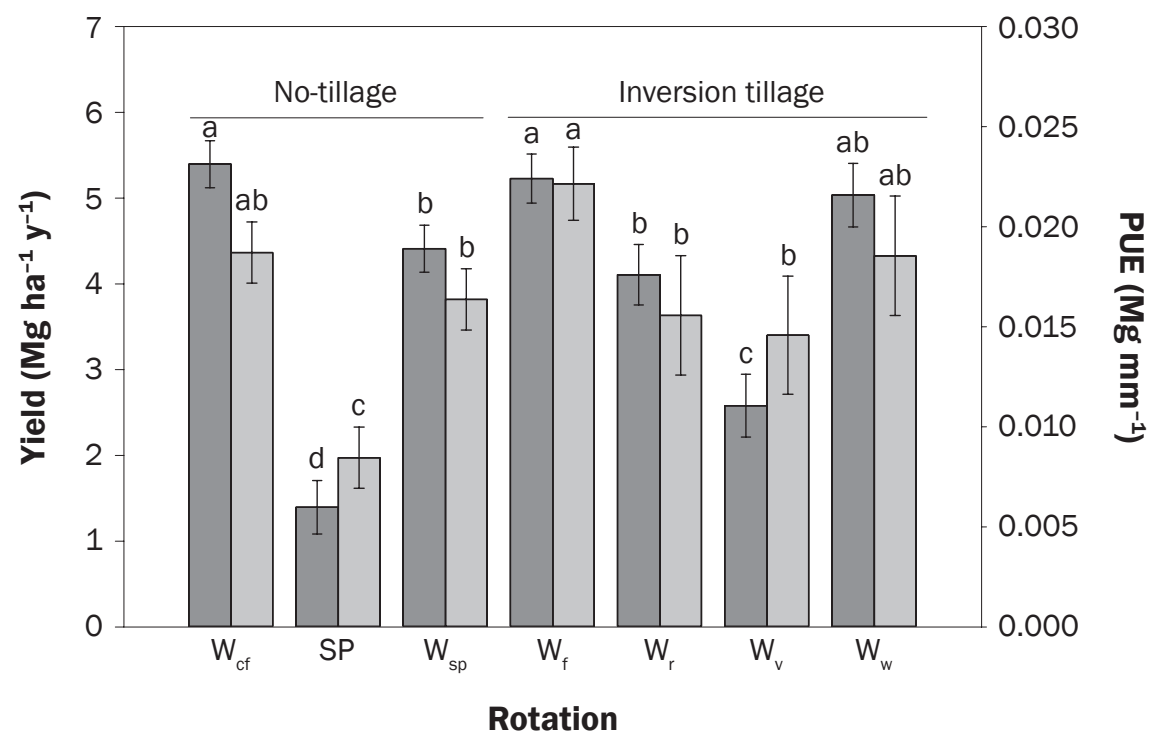

\section{Legend}

$\square$ Yield (Mg ha $\left.{ }^{-1} \mathrm{y}^{-1}\right) \quad \square$ PUE $\left(\mathrm{Mg} \mathrm{mm}^{-1}\right)$ 
explain the small PUE value in the SP phase of the four year rotation.

The most direct comparisons in the two cropping systems are between $\mathrm{W}_{c f}$ and $\mathrm{W}_{\mathrm{f}}$, and $\mathrm{CF}$ and $\mathrm{F}$ phases, where tillage treatment differences would have been least confounded by crop type and cropping intensity. With greater crop residue cover and less soil disturbance, one would expect improved precipitation capture and soil water storage under the no-tillage rather than inversion tillage management. Contrary to our expectations, yield or PUE were not significantly different between $\mathrm{W}_{\mathrm{cf}}$ and $\mathrm{W}_{\mathrm{f}}$ (figure 2). As such, these results provide no support for superior soil water condition in either tillage system. These results are similar to those reported resulting from an examination of a two-year winter wheat-fallow rotation comparing no-tillage to fallow maintained using a single pass-undercutter system, and a comparison of no-tillage to inversion tillage using an undercutter in the intermediate precipitation zone of the IPNW (Williams and Wuest 2014; Williams et al. 2015). The lowest values of soil water were found in the $\mathrm{W}_{\mathrm{r}}$, with only one year of data from this rotation in 2005 (table 1). This crop was necessary to get one-half of the inversion tillage drainage into an alternate phase from with the other half, and it was grown in the year with the lowest annual precipitation recorded (309.7 $\mathrm{mm}$ [12.19 in]). Despite these conditions, $\mathrm{W}_{\mathrm{r}}$ crop yield and precipitation use efficiency were not significantly lower than the other crops not preceded by fallow (figure 2).

Soil water in the $1.8 \mathrm{~m}(6 \mathrm{ft})$ soil profile measured at its minimum in late summer before autumn precipitation and recharge was not significantly different between no-tillage $(132.7 \pm 3.7 \mathrm{~mm}[5.23 \pm 0.15$ in]) and inversion tillage $(125.5 \pm 5.8 \mathrm{~mm}$ [4.94 \pm 0.23 in]) drainages, but there were differences among the various phases of each tillage and rotation type (figure 3 ). The $\mathrm{CF}$ and $\mathrm{F}$ held the most water in the fall, as would be expected after a year of fallow, and were not significantly different. There was significantly more water in CF than any of the no-tillage crops $\left(\mathrm{W}_{\mathrm{cf}}, \mathrm{SP}, \mathrm{W}_{\mathrm{sp}}\right)$. The variability in inversion tillage crops, however, was substantial enough that there was no significant differences between $\mathrm{F}$ and the inverse tillage crop phases. Water in the soil profile $(1.8 \mathrm{~m}[6 \mathrm{ft}])$ measured during mid-winter and the wettest part of the year

\section{Figure 3}

Mean soil water in soil profile before autumn recharge in northeastern Oregon. Letters above bars indicate significant differences between columns $(p \leq 0.05)$. $\mathrm{W}_{\mathrm{cf}}=$ winter wheat following chemical fallow. $S P=$ spring peas following winter wheat. $W_{s p}=$ winter wheat following spring peas. $W_{f}$ = winter wheat following inversion tillage fallow. $\mathrm{W}_{\mathrm{r}}=$ recropped winter wheat following winter wheat. $\mathrm{W}_{v}=$ volunteer winter wheat following recropped winter wheat. $\mathrm{W}_{\mathrm{w}}=$ winter wheat following volunteer winter wheat. Chemical (CF) or inversion tillage (F) fallow was 14 months.

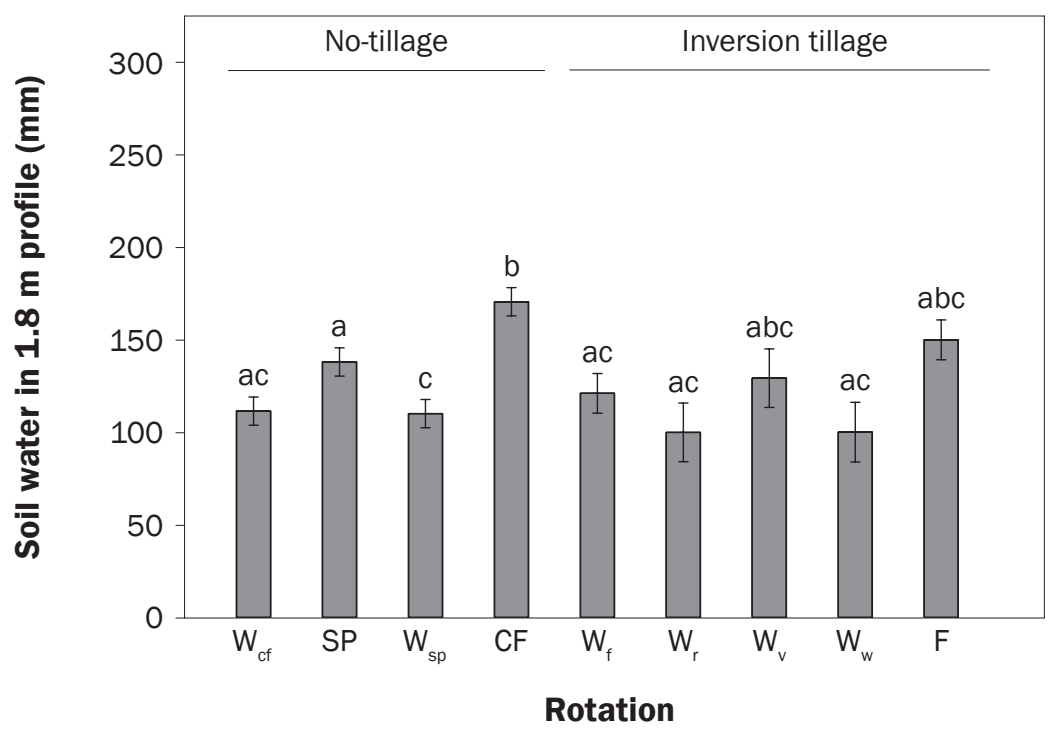

Legend

$\square$ Minimum soil water in $1.8 \mathrm{~m}$ profile $(\mathrm{mm})$

shows a generally even recharge in all phases of both rotations (figure 4).

Soil water at incremental depths were different among the in-crop phases in autumn at the $30 \mathrm{~cm}(1 \mathrm{ft}), 60 \mathrm{~cm}(2 \mathrm{ft})$ and in the $180 \mathrm{~cm}$ depths $(6 \mathrm{ft})$ (table 4$).$ In the $30 \mathrm{~cm}$ depth of the soil profile, there was significantly more water in the no-tillage $(1.5 \pm$ $0.0 \mathrm{~mm}[0.13 \pm 0.00 \mathrm{in}])$ than in the inversion tillage $(1.2 \pm 0.1 \mathrm{~mm}[0.10 \pm 0.01$ in]). The largest differences were between $\mathrm{W}_{\text {sp }}$ and CF in the no-tillage, which had more soil water than in $\mathrm{W}_{\mathrm{r}}$ and $\mathrm{W}_{\mathrm{f}}$ in the inversion tillage. There was no difference between inverse and no-tillage drainages in the $60 \mathrm{~cm}$ depth, although there were differences among individual phases of each rotation with significantly more soil water in the $\mathrm{F}$ than $\mathrm{W}_{\mathrm{cf}}, \mathrm{SP}, \mathrm{W}_{\mathrm{f}}, \mathrm{W}_{\mathrm{r}}, \mathrm{W}_{\mathrm{v}}, \mathrm{W}_{\mathrm{w}}$ (table 4). These findings can be attributed to an abundance of crop residue on the soil surface in the no-tillage $\mathrm{W}_{\mathrm{sp}}$ and $\mathrm{CF}$ compared to inversion tillage $\mathrm{W}_{\mathrm{r}}^{\mathrm{sp}}$ and $\mathrm{W}_{\mathrm{f}}$ crops (Bristow et al. 1986), and that CF and $F$ were storing while cropped plots were depleting water. The abundance of soil water in the $60 \mathrm{~cm}$ depth in F can be accounted for by the tra- ditional use of tillage to trap soil water below an insulating layer of disturbed soil. The low soil water values found in the $180 \mathrm{~cm}$ depth in the $\mathrm{W}_{\mathrm{v}}$ and $\mathrm{W}_{\mathrm{w}}$ reflect three and then four years of continuous crops without an opportunity for recharge.

Our spring pea (chickpeas or dry green peas) were not very productive, but the $\mathrm{W}_{\mathrm{r}}$ in the inversion tillage produced as well as the $\mathrm{W}_{\mathrm{sp}}$ (figure 2), suggesting that a recropped winter wheat would be better matched for this lower precipitation regime. Spring planting of small grain or canola (Brassica spp.) are potential alternatives to recropped winter wheat, and are prescribed to help control annual weeds such as cheat grass (Bromus tectorum) (Veseth et al. 1994) or pathogens (Schillinger et al. 2003), and proven agronomically and economically successful under $280 \mathrm{~mm}$ (11 in) annual precipitation (Machado et al. 2015; Veseth et al. 1994). Ongoing research by USDA Agricultural Research Service (ARS) and Oregon State University scientists near Pendleton and Moro, Oregon, is examining how spring and winter canola might contribute to more intensive rotations for this region. 


\section{Figure 4}

Mean soil water in soil profile in mid-winter when recharge is at or near complete, northeastern Oregon. Letters above bars indicate significant differences between columns $(p \leq 0.05)$.

$\mathrm{W}_{\mathrm{cf}}=$ winter wheat following chemical fallow. $\mathrm{SP}=$ spring peas following winter wheat. $\mathrm{W}_{\mathrm{sp}}=$ winter wheat following spring peas. $W_{f}=$ winter wheat following inversion tillage fallow. $W_{r}=$ recropped winter wheat following winter wheat. $W_{v}=$ volunteer winter wheat following recropped winter wheat. and $\mathrm{w}_{\mathrm{w}}=$ winter wheat following volunteer winter wheat. Chemical (CF) or inversion tillage (F) fallow was 14 months.

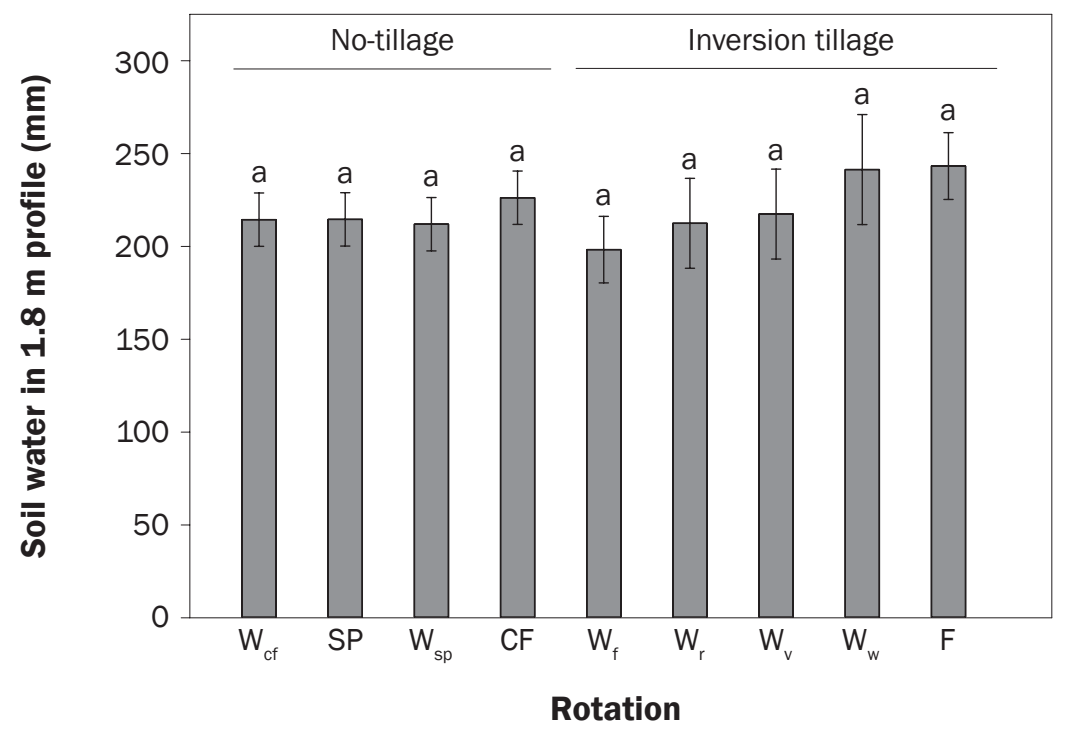

Legend

Minimum soil water in $1.8 \mathrm{~m}$ profile $(\mathrm{mm})$
The least amount of recharge occurred in the $\mathrm{W}_{\mathrm{cf}}$, which followed CF with the largest amount of soil water the previous autumn (figure 3). Although water stored mid-winter in fallow was not significantly different, the amount needed to recharge the inversion tillage $\mathrm{W}_{\mathrm{f}}$ soil profile was significantly greater than in no-tillage $\mathrm{W}_{\mathrm{cf}}$. This difference appears to be the result of a nonsignificant but visibly apparent lower autumn soil water value in the inversion tillage F (figure 3). Differences deeper in the profile following recharge table 6 were likely the result of differences carried over from autumn. Substantial runoff from either drainage did not occur during time periods when changes in soil water from autumn to fall were measured (Williams et al. 2014).

The goal of this research was to evaluate the crop production, precipitation use efficiency, and soil water regimes of two tillage practices in the intermediate precipitation zone of the INPNW. The differences in crop productivity were not significantly different (figure 2), suggesting that late twentieth century problems with soil compaction, weed control, and seed bed preparation have been resolved by experimentation and trial and error. We found that PUE in the traditional inversion tillage system was better than in an intensive cropping system under no-tillage, a result we attribute to the poor performance of our chosen spring crop (figure 2). Our results show more soil surface $(30 \mathrm{~cm}$ [1 $\mathrm{ft}$ ) water in the $\mathrm{W}_{\mathrm{cf}}$ than $\mathrm{W}_{\mathrm{f}}$ before seeding (table 4). This result is contrary to expecta-
Analysis of the change in soil water through the entire $1.8 \mathrm{~m}(6 \mathrm{ft})$ profile in winter resulted in no significant differences between no-tillage $(93.9 \pm 16.3 \mathrm{~mm} \mathrm{[3.70}$ $\pm 0.64 \mathrm{in}])$ and inversion tillage $(99.8 \pm 16.4$ $\mathrm{mm}[3.93 \pm 0.64 \mathrm{in}])$ drainages; however, there were significant differences in recharge among rotations (table 5). Large recharge values in no-tillage SP, CF, and inversion tillage $\mathrm{W}_{\mathrm{v}}, \mathrm{W}_{\mathrm{w}}$, and $\mathrm{F}$ were expected because they followed a crop, or series of crops, that would have substantially depleted soil water reserves.

Table 4

Autumn pre-seeding mean soil water for crop years 2004 through 2008 in northeastern Oregon.

\begin{tabular}{|c|c|c|c|c|c|c|c|c|c|}
\hline \multirow[b]{3}{*}{$\begin{array}{l}\text { Depth } \\
\text { (cm) }\end{array}$} & \multicolumn{9}{|c|}{ Soil water $\left(\mathrm{mm} \mathrm{mm}^{-1}\right)$} \\
\hline & \multicolumn{4}{|l|}{ No-tillage } & \multicolumn{5}{|l|}{ Inversion tillage } \\
\hline & $\mathrm{W}_{\mathrm{cf}}{ }^{*}$ & SP & $W_{s p}$ & CF & $w_{f}$ & $W_{r}$ & $w_{v}$ & $\mathbf{w}_{w}$ & $\mathbf{F}$ \\
\hline 30 & $0.11 \pm 0.01 \mathrm{abc}$ & $0.11 \pm 0.01 \mathrm{abc}$ & $0.14 \pm 0.01 a$ & $0.13 \pm 0.01 a b$ & $0.09 \pm 0.01 \mathrm{c}$ & $0.06 \pm 0.02 c$ & $0.10 \pm 0.02 a b c$ & $0.08 \pm 0.02 b c$ & $0.11 \pm 0.01 \mathrm{abc}$ \\
\hline 60 & $0.12 \pm 0.01 a$ & $0.12 \pm 0.01 \mathrm{a}$ & $0.14 \pm 0.01 a b$ & $0.14 \pm 0.01 a b$ & $0.11 \pm 0.01 \mathrm{a}$ & $0.09 \pm 0.02 a$ & $0.12 \pm 0.02 \mathrm{a}$ & $0.10 \pm 0.02 a b$ & $0.16 \pm 0.01 b$ \\
\hline 90 & $0.13 \pm 0.01 a$ & $0.12 \pm 0.01 a$ & $0.13 \pm 0.01 a$ & $0.14 \pm 0.01 \mathrm{a}$ & $0.13 \pm 0.01 \mathrm{a}$ & $0.11 \pm 0.02 a$ & $0.15 \pm 0.02 a$ & $0.10 \pm 0.02 a$ & $0.15 \pm 0.01 a$ \\
\hline 150 & $0.15 \pm 0.01 a$ & $0.14 \pm 0.01 \mathrm{a}$ & $0.15 \pm 0.01 a$ & $0.16 \pm 0.01 \mathrm{a}$ & $0.3 \pm 0.01 a$ & $0.12 \pm 0.02 a$ & $0.13 \pm 0.02 a$ & $0.09 \pm 0.02 a$ & $0.14 \pm 0.01 a$ \\
\hline 180 & $0.17 \pm 0.01 \mathrm{abc}$ & $0.17 \pm 0.01 a b$ & $0.18 \pm 0.01 a$ & $0.16 \pm 0.01 \mathrm{abc}$ & $0.15 \pm 0.01 \mathrm{abc}$ & $0.14 \pm 0.01 \mathrm{abc}$ & $0.13 \pm 0.01 b c$ & $0.12 \pm 0.01 \mathrm{c}$ & $0.16 \pm 0.01 \mathrm{abc}$ \\
\hline
\end{tabular}

Notes: $\mathrm{W}_{\mathrm{cf}}=$ winter wheat following chemical fallow. $\mathrm{SP}=$ spring peas following winter wheat. $\mathrm{W}_{\mathrm{sp}}=$ winter wheat following spring peas. $\mathrm{W}_{\mathrm{f}}=$ winter wheat following inversion tillage fallow. $W_{r}=$ recropped winter wheat following winter wheat. $W_{v} \stackrel{s p}{=}$ volunteer winter wheat following recropped winter wheat. $W_{w}=$ winter wheat following volunteer winter wheat. Chemical (CF) or inversion tillage (F) fallow was 14 months.

$* \mathrm{~W}_{\mathrm{cf}}, \mathrm{SP}, \mathrm{W}_{\mathrm{sp}}$, and $\mathrm{CF}$ cropped using one-pass no-till, chemical fallow technology. $\mathrm{W}_{\mathrm{f}}, \mathrm{W}_{\mathrm{v}}, \mathrm{W}_{\mathrm{w}}, \mathrm{W}_{\mathrm{r}}$, and $\mathrm{F}$ were managed with a combination of inversion tillage practices (moldboard plow, residue burned, shallow disking, and rod weeding in combination with herbicide applications. 
Table 5

Soil water increase between autumn pre-seeding and mid-winter in $1.8 \mathrm{~m}$ profile for crop years 2004 through 2008 measured in northeastern Oregon.

\begin{tabular}{|c|c|c|c|c|c|c|c|c|c|}
\hline \multirow[b]{3}{*}{$\begin{array}{l}\text { Depth } \\
\text { (cm) }\end{array}$} & \multicolumn{9}{|c|}{ Soil water $(\mathrm{mm})$} \\
\hline & \multicolumn{4}{|l|}{ No-tillage } & \multicolumn{5}{|l|}{ Inversion tillage } \\
\hline & $\mathrm{W}_{\mathrm{cf}}{ }^{*}$ & SP & $\mathbf{W}_{\mathrm{sp}}$ & CF & $w_{f}$ & $W_{r}$ & $w_{v}$ & $\mathbf{w}_{\mathrm{w}}$ & $\mathbf{F}$ \\
\hline 180 & $63.8 \pm 15.1 a$ & $110.9 \pm 15.1 b$ & $84.9 \pm 15.1 \mathrm{~cd}$ & $109.6 \pm 15.1 b$ & $94.6 \pm 15.6 \mathrm{bcd}$ & $74.5 \pm 16.6 \mathrm{ad}$ & $118.7 \pm 16.6 b$ & $111.6 \pm 16.6 \mathrm{bcd}$ & $106.7 \pm 15.6 b c$ \\
\hline
\end{tabular}

\section{Table 6}

Mean soil water values at incremental depths measured in winter for crop years 2004 through 2008 measured in northeastern Oregon.

\begin{tabular}{|c|c|c|c|c|c|c|c|c|c|}
\hline \multirow{2}{*}{$\begin{array}{l}\text { Depth } \\
\text { (cm) }\end{array}$} & \multicolumn{9}{|c|}{ Soil water $\left(\mathrm{mm} \mathrm{mm}^{-1}\right)$} \\
\hline & $\mathrm{w}_{\mathrm{cf}}{ }^{*}$ & SP & $W_{s p}$ & CF & $w_{f}$ & $w_{r}$ & $\mathbf{w}_{\mathrm{v}}$ & $\mathbf{w}_{w}$ & $\mathbf{F}$ \\
\hline 30 & $0.24 \pm 0.01 a$ & $0.23 \pm 0.01 a$ & $0.23 \pm 0.01 a$ & $0.23 \pm 0.01 a$ & $0.21 \pm 0.02 a$ & $0.20 \pm 0.02 a$ & $0.24 \pm 0.02 a$ & $0.22 \pm 0.02 \mathrm{a}$ & $0.23 \pm 0.02 \mathrm{a}$ \\
\hline 60 & $0.22 \pm 0.01 a$ & $0.20 \pm 0.01 \mathrm{ab}$ & $0.20 \pm 0.01 \mathrm{ab}$ & $0.20 \pm 0.01 \mathrm{ab}$ & $0.22 \pm 0.01 \mathrm{ab}$ & $0.16 \pm 0.02 b$ & $0.20 \pm 0.02 \mathrm{ab}$ & $0.22 \pm 0.02 \mathrm{ab}$ & $0.20 \pm 0.01 \mathrm{ab}$ \\
\hline 150 & $0.20 \pm 0.01 a$ & $0.15 \pm 0.01 \mathrm{bcd}$ & $0.18 \pm 0.01 b c$ & $0.15 \pm 0.01 \mathrm{bcd}$ & $0.20 \pm 0.01 a b$ & $0.15 \pm 0.02 \mathrm{bcd}$ & $0.12 \pm 0.02 d$ & $0.13 \pm 0.02 \mathrm{bcd}$ & $0.12 \pm 0.01 d$ \\
\hline 180 & $0.20 \pm 0.01 \mathrm{a}$ & $0.16 \pm 0.01 b c$ & $0.17 \pm 0.01 b$ & $0.16 \pm 0.01 b c$ & $0.19 \pm 0.01 \mathrm{ab}$ & $0.15 \pm 0.01 c$ & $0.15 \pm 0.01 b c$ & $0.13 \pm 0.01 b c$ & $0.13 \pm 0.01 c$ \\
\hline \multicolumn{10}{|c|}{$\begin{array}{l}\text { Notes: } W_{c f}=\text { winter wheat following chemical fallow. } S P=\text { spring peas following winter wheat. } W_{s p}=\text { winter wheat following spring peas. } F=\text { inversion } \\
\text { tillage fallow. } W_{f}=\text { winter wheat following inversion tillage fallow. } W_{r}=\text { recropped winter wheat following winter wheat. } W_{v}=\text { volunteer winter wheat fol- } \\
\text { lowing recropped winter wheat. } W_{w}=\text { winter wheat following volunteer winter wheat. Chemical }(C F) \text { or inversion tillage }(F) \text { fallow was } 14 \text { months. }\end{array}$} \\
\hline
\end{tabular}

tions for no-tillage in this region, where a major impediment is a lack of soil water in the seed zone or near surface soil for planting depths from 2.54 to $10 \mathrm{~cm}$ ( 1 to 4 in). The purpose of inversion tillage and seeding with a deep-furrow drill $(13$ to $30 \mathrm{~cm}$ [5 to 10 in]) is to gain access to the greater amount of water below the tillage layer, as was the case in the $60 \mathrm{~cm}(2 \mathrm{ft})$ depth in this research (table 4). In the intermediate precipitation zone where this research was conducted, a combination of no-tillage and abundant crop residue can match inversion tillage winter wheat production levels, but we do not recommend increasing cropping intensity with an introduction of spring seeded chickpeas or dry green peas.

\section{Summary and Conclusions}

Early attempts at adopting no-tillage in northeastern Oregon were unsuccessful, which was attributed to poor soil water conditions. Crop yields, soil water, and PUE values in the no-tillage, four-year intensive crop rotation were not significantly different and compared favorably to values measured in the inversion tillage crops. The inversion tillage system had significantly better PUE values than the no-tillage system, although the directly comparable $\mathrm{W}_{\mathrm{f}}$ and $\mathrm{W}_{\mathrm{cf}}$ phases were not significantly different. Based on these results, replacing the spring pea crop with a small grain would result in improved performance in the no-tillage treatment.

\section{Acknowledgements}

The authors thank cooperating landowner Clinton Reeder and faculty from the Columbia Basin Agriculture Research Center-Oregon State University (Dan Ball [emeritus professor], Richard Smiley [emeritus professor], and Don Wysocki [associate professor]) for advice concerning weed, disease, and crop management. Field work, instrumentation, laboratory analysis, and data collection were conducted by Daryl Haasch (hydrologic technician, Columbia Plateau Conservation Research Center - USDA Agricultural Research Service [ARS]-Columbia Plateau Conservation Research Center [CPCRC], retired), Bob Correa (agricultural research technician - USDA ARS-CPCRC, retired),
Tami Johlke (biological science technician CPCRC USDA ARS), Chris Roager (chemist - USDA ARS-CPCRC, retired), Scott Oviatt (snow survey supervisor, USDA Natural Resources Conservation Service [NRCS]), and numerous high school and college students. We appreciate the constructive comments made by two anonymous reviewers and our CPCRC colleagues Tami Johlke and Catherine Reardon (research microbiologist) and Stewart Wuest (soil scientist). This research was conducted under USDA ARS national programs Agricultural System Competitiveness and Sustainability (NP\#216) and Climate Change, Soils, and Emissions (NP\#212).

\section{References}

Bonta, J.V. 1998. Modified drop-boxweir for monitoring flows from erosion plots and small watersheds. Transactions of the American Society of Agricultural Engineers 41(3):565-573.

Bragg, D., J.W. Burns, F. Muehlbauer, and T. McGreevy. 2000. Crop profile for peas (dry) in Washington. Washington State University and WSU Cooperative Extension, with NSF Center for Integrated Pest Managment, North Carolina State University, and USDA-NIFA. http:// www.ipmcenters.org/cropprofiles/docs/wapeas-dry.pdf. 
Bristow, K.L., G.S. Campbell, R.I. Papendick, and L.F. Elliott. 1986. Simulation of heat and moisture transfer through a surface residue - soil system. Agricultural and Forest Meteorology 36(3):193-214.

Chen, C., and W.A. Payne. 2001. Measured and modeled unsaturated hydraulic conductivity of a Walla Walla silt loam. Soil Science Society American Journal 65(5):1385-1391

Duff,B., P.E. Rasmussen, and R.W.Smiley. 1995.Wheat/fallow systems in semi-arid regions of the Pacific NW America. In Agricultural Sustainability: Economic, Environmental and Statistical Considerations. Ed. V. Barnett, R. Payne, and R. Steener, 85-111. London: Wiley.

Felton, W., H. Marcellos, and R. Martin. 1995. A comparison of three fallow management strategies for the long-term productivity of wheat in northern New South Wales. Australian Journal of Experimental Agriculture 35(7):915-921.

Floyd, D.A., and J.E. Anderson. 1982. A new point interception frame for estimating cover of vegetation. Plant Ecology 50(3):185-186.

Glysson, G.D., and J.R. Gray. 2002. Total suspended solids data for use in sediment studies. In Turbidity and Other Sediment Surrogates Workshop. (ed.). Reno, NV, April 30-May 2, 2002.

Gollany, H.T., R.W. Rickman, Y. Liang, S.L. Albrecht, S. Machado, and S. Kang. 2011. Predicting agricultural management influence on long-term soil organic carbon dynamics: Implications for biofuel production. Agronomy Journal 103(1):234-246.

Hammel, J.E. 1995. Long-term tillage and crop rotation effects on winter wheat production in northern Idaho. Agronomy Journal 87(1):16-22.

Huggins, D.R., R.S. Karow, H.P. Collins, and J.K. Ransom. 2011. Introduction: Evaluating long-term impacts of harvesting crop residues on soil quality. Agronomy Journal 103(1):230-233.

Hurlbert, S.H. 1984. Pseudoreplication and the design of ecological field experiments. Ecological Monographs 54(2):187-211.

Johnson, D.R., and A.J. Makinson. 1988. Soil survey of Umatilla County area, Oregon. Washington, DC: USDA Soil Conservation Service, US Government Printing Office.

Johnson, M.D., and B. Lowery. 1985. Effect of three conservation tillage practices on soil temperature and thermal properties. Soil Science Society of American Journal 49(6):1547-1552.

Littell, R.C., G.A. Milliken, W.W. Stroup, R.D.Wolfinger, and O. Schabenberger. 2006. SAS for Mixed Models, Second Edition, 97. Cary, NC: SAS Publishing, SAS Institute Inc.

Machado, S., L. Pritchett, and S. Petrie. 2015. No-tillage cropping systems can replace traditional summer fallow in north-central Oregon. Agronomy Journal 107(5):1863-1877.

Payne, W.A., P.E. Rasmussen, C. Chen, R. Goller, and R.E. Ramig. 2000. Precipitation, temperature and tillage effects upon productivity of a winter wheat-dry pea rotation. Agronomy Journal 92(5):933-937.

Rasmussen, P.E., and W.J. Parton. 1994. Long-term effects of residue management in wheat-fallow: I. Inputs, yield, and soil organic matter. Soil Science Society of America Journal 58(2):523-530.

Rasmussen, P.E., S.L. Albrecht, and R.W. Smiley. 1998 Soil $\mathrm{C}$ and $\mathrm{N}$ changes under tillage and cropping systems in semi-arid Pacific Northwest agriculture. Soil and Tillage Research 47(3-4):197-205.

SAS. 2012. SAS/STAT 9.4 User's Guide. SAS Institute Inc., Cary, NC, USA.

Schillinger, W.F., R.I. Papendick, S.O. Guy, P.E. Rasmussen, and C. van Kessel. 2003. Dryland cropping in the western United States, Ch. 2: Conservation Tillage Systems and Equipment, December 2003. In Pacific Northwest Conservation Tillage Handbook Series No. 28.365-393. University of Idaho Cooperative Extension System, Oregon State University Extension Service, and Washington State University Extension.

Schillinger, W.F., and D.L. Young. 2004. Cropping systems research in the world's driest rainfed wheat region. Agronomy Journal 96(4):1182-1187.

Schillinger, W.F., and R.I. Papendick. 2008. Then and now: 125 years of dryland wheat farming in the Inland Pacific Northwest. Agronomy Journal 100(Supplement_3):S-166-S-182.

Smiley, R.W., M.C. Siemens, T.M. Gohlke, and J.K. Poore. 2005. Small grain acreage and management trends for eastern Oregon and Washington, 30-50. Corvallis, OR: Agricultural Experiment Station, Oregon State University, and USDA Agricultural Research Service.

USDI-BoR (US Bureau of Reclamation). 2001. Chapter 8, Flumes; 10. Parshall flumes. In Water Measurement Manual. US Government Printing Office stock number 024-003-00180-5. Washington, DC: Bureau of Reclamation, US Department of the Interior.

Veseth, R., A. Ogg, D.C. Thill, D.J. Wysocki, F. Bailey, T.M. Gohlke, and H. Riehle. 1994. Managing downy brome under conservation tillage systems in the Inland Northwest crop-fallow region, Ch. 5. In Pacific Northwest Conservation Tillage Handbook Series 8 . University of Idaho Cooperative Extension System, Oregon State University Extension Service, and Washington State University Cooperative Extension.

Williams, J.D., D.E. Wilkins, C.L. Douglas, and R.W. Rickman. 2000. Mow-plow crop residue management influence on soil erosion in north-central Oregon. Soil and Tillage Research 55(1-2):71-78.

Williams, J.D., H.T. Gollany, M.C. Siemens, S.B. Wuest, and D.S. Long. 2009. Comparison of runoff, soil erosion, and winter wheat yields from no-till and inversion tillage production systems in northeastern Oregon. Journal of Soil and Water Conservation 64(1):43-52, doi:10.2489/jswc.64.1.43.

Williams, J.D., and D.S. Long. 2011. Intensive crop rotation yield and economic performance in minimum tillage and no tillage in Northeastern Oregon. Crop Management 10, December 2010.

Williams, J.D., and S.B. Wuest. 2011. Tillage and no-tillage conservation effectiveness in the intermediate precipitation zone of the inland Pacific Northwest, United States. Journal of Soil and Water Conservation 66(4):242-249, doi:10.2489/jswc.66.4.242

Williams, J.D., and S.B. Wuest. 2014. Soil water dynamics in continuous winter wheat in the semiarid Pacific Northwest, USA. Soil Science Society of America Journal 78(2):571-578

Williams, J.D., S.B. Wuest, and D.S. Long. 2014. Soil and water conservation in the Pacific Northwest through no-tillage and intensified crop rotations. Journal of Soil and Water Conservation 69(6):495-504, doi:10.2489/ jswc.69.6.495.

Williams, J.D., S.B. Wuest, and D.S. Robertson. 2015. Soil water and water-use efficiency in no-tillage and sweep tillage winter wheat production in Northeastern Oregon. Soil Science Society of America Journal 79(4):1206-1212.

Wuest, S.B., and M.K. Corp. 2011. One-pass tillage for summer fallow under arid summer conditions. Crop Management 10(1).

Wuest, S.B., and W.F. Schillinger. 2011. Evaporation from high residue no-till versus tilled fallow in a dry summer climate. Soil Science Society of American Journal 75(4):1513-1519

Zuzel, J.F., R.R. Allmaras, and R.N. Greenwalt. 1982 Runoff and soil erosion on frozen soils in northeastern Oregon. Journal of Soil and Water Conservation $37(6): 351-354$ 